\title{
Molecular detection of Ehrlichia canis in Rhipicephalus sanguineus (s.l.) ticks in dogs and their domestic environment in Cuiaba, MT, Brazil
}

\author{
Detecção molecular de Ehrlichia canis em carrapatos Rhipicephalus \\ sanguineus (s.l.), em cães e em seus ambientes domésticos em \\ Cuiabá, MT, Brasil
}

\author{
Jackeliny dos Santos Costa ${ }^{1}$, Andréia Lima Tomé Melo ${ }^{2}$, Rute Witter ${ }^{1,3}$, Thábata dos Anjos Pacheco ${ }^{1,3}$, \\ Cristiane Silva Chitarra ${ }^{1}$, Izabelle Thayná Soares Carvalho ${ }^{1}$, Luciano Nakazato ${ }^{1}$, \\ Valéria Dutra ${ }^{1}$, Richard de Campos Pacheco ${ }^{1}$, Daniel Moura de Aguiar ${ }^{1}$ (i)

\footnotetext{
${ }^{1}$ Universidade Federal de Mato Grosso, Faculdade de Medicina Veterinária, Laboratório de Virologia e Rickettsioses, Cuiabá - MT, Brazil ${ }^{2}$ Universidade de Cuiabá, Curso de Medicina Veterinária, Cuiabá - MT, Brazil

${ }^{3}$ Instituto Federal de Educação Ciência e Tecnologia de Rondônia, Porto Velho - RO, Brazil
}

\begin{abstract}
The central region of Brazil is known to be an endemic area for canine ehrlichiosis. Therefore, this study aims to determine the prevalence rates of $E$. canis infection in dogs and in Rhipicephalus sanguineus ticks collected from the dogs and their home environments. Serum samples and genomic DNA from the blood of 20 dogs and 299 ticks were analyzed by IFA and PCR assays in order to detect Ehrlichia canis antibodies and DNA. Nine (45\%) of the 20 dogs were seropositive for E. canis, with titers ranging from 80 to 10240, and 6 dogs (30\%) were positive for Ehrlichia spp. by PCR. Five free-living ticks were positive $(2.89 \%, 95 \%$ confidence interval: $0.94-6.62 \%)$, as were six ticks attached to dogs (4.76\%; 95\% CI: $1.77-10.0 \%)$. The two groups showed a similar infection rate ( $\mathrm{P}=0.395)$. Partial $d s b$ DNA sequences of two samples from ticks were identical to each other and 100\% (350/350 nucleotides) were identical to E. canis. Despite the high serological and molecular rates of canine ehrlichiosis in Cuiabá, the prevalence among infected ticks was lower than that found among dogs. However, adult ticks may remain infective much longer to ensure their infestation and infection of susceptible dogs.
\end{abstract}

Keywords: Anaplasmataceae. Vector. Prevalence. PCR. Antibody.

\section{RESUMO}

A região central do Brasil é caracterizada como uma área endêmica para erliquiose canina. Devido a isso, o presente estudo objetivou determinar a prevalência de infecção em cães e seus carrapatos $R$. sanguineus, coletados a partir do mesmo ambiente. As amostras de soro e DNA genômico de sangue de 20 cães e 299 carrapatos foram testadas por RIFI e PCR a fim de detectar anticorpos e DNA de Ehrlichia canis. Do total, 9 (45\%) eram soropositivos para E. canis com títulos variando de 80 a 10240 e 6 cães (30\%) positivos para Ehrlichia spp. por PCR. Cinco carrapatos de vida livre (2,89\%; intervalo de confiança 95\%: 0,94-6,62\%), e 6 carrapatos fixados em cães (4,76\%; IC 95\%: 1,77-10,0\%) foram positivos. A taxa de infecção foi semelhante entre ambos os grupos $(\mathrm{P}=0.395)$. As sequências parciais do gene $d s b$ de 2 amostras de carrapatos foram idênticas entre si e 100\% (350/350) idênticas à E. canis. Apesar das altas taxas sorológicas e moleculares de erliquiose canina em Cuiabá, a prevalência de carrapatos infectados foi menor que o encontrado em cães. Por outro lado, os carrapatos adultos podem permanecer infectados por tempo suficiente para garantir a infestação e infecção aos cães susceptíveis.

Palavras-chave: Anaplasmataceae. Vetor. Prevalência. PCR. Anticorpo. 
Correspondence to:

Daniel Moura de Aguiar

Universidade Federal de Mato Grosso, Faculdade de Medicina

Veterinária, Hospital Veterinário, Laboratório de Virologia e

Rickettsioses

Av. Fernando Corrêa, 2367, Boa Esperança

CEP: 78060-900, Cuiabá - MT, Brazil

e-mail:danmoura@ufmt.br

Received: January 17, 2019

Approved: May 05, 2019
How to cite: Costa JS, Melo ALT, Witter R, Pacheco TA, Chitarra CS, Carvalho ITS, Nakazato L, Dutra V, Pacheco RC, Aguiar DM. Molecular detection of Ehrlichia canis in Rhipicephalus sanguineus (s.l.) ticks in dogs and their domestic environment in Cuiaba, MT, Brazil. Braz J Vet Res Anim Sci. 2019;56(2):e153661. https://doi.org/10.11606/ issn.1678-4456.bjvras.2019.153661

\section{Introduction}

The genus Ehrlichia belongs to the order Rickettsiales, family Anaplasmataceae and consists of six recognized species, namely, E. canis, E. chaffeensis, E. ewingii, E. muris, E. ruminantium and E. minasensis sp. nov. (Cabezas-Cruz et al., 2016; Dumler et al., 2001), which naturally infect a wide variety of vertebrate hosts. All currently known Ehrlichia species are transmitted by ticks of the family Ixodidae (Bremer et al., 2005). The brown dog tick Rhipicephalus sanguineus is the most widespread tick in the world and belongs to the so-called 'Complex R. sanguineus' or $R$. sanguineus group, which includes at least five species morphologically related in the Old World (Pegram et al., 1987; Walker et al., 2000). In addition to dogs, this tick can occasionally parasitize other hosts, including humans; it is highly adapted to live in human dwellings and is active throughout the year, not only in tropical and subtropical regions, but also in some temperate zones (Dantas-Torres, 2010). Rhipicephalus sanguineus not only weakens dogs through high infestations, but is also the main vector of Ehrlichia canis, the agent of canine monocytic ehrlichiosis (Moraes-Filho et al., 2011).

According to the review of Vieira et al. (2011) prevalence rates of anti-Ehrlichia spp. antibodies on dogs in the state of Mato Grosso showed higher prevalence rates of anti-Ehrlichia spp. antibodies than any other region in the country (Vieira et al., 2011). Studies carried out in various neighborhoods of the city of Cuiabá have also found high prevalence rates of E. canis infection in dogs (Makino et al., 2015; Silva et al., 2010; Witter et al., 2013). Based on this information and in view of the importance of ehrlichiosis in the region, the purpose of this study was to detect the presence of E. canis and anti-E. canis antibodies in pet dogs in Cuiabá and to evaluate the prevalence rates of E. canis infection in the $R$. sanguineus ticks collected from the dogs and their home environments in 17 neighborhoods in the city of Cuiabá, MT.

\section{Materials and Methods}

\section{Study area and sample collection}

Cuiabá is located in the state of Mato Grosso, Brazil, under the coordinates $15^{\circ} 35^{\prime} 46^{\prime \prime}$ South and $56^{\circ} 05^{\prime} 48^{\prime \prime}$ West, at 176 meters above sea level. The city, with a population of 607.153 (Instituto Brasileiro de Geografia e Estatística, 2018), has a warm tropical and sub-humid climate. Samples from dogs and ticks were collected from February 2012 to October 2014 in 17 neighborhoods (representing the eastern, western, northern and southern areas of the city of Cuiabá).

This study involved 20 male or female dogs of various ages and breeds treated at the Veterinary Hospital of the Federal University of Mato Grosso, which presented infestation by $R$. sanguineus (s.l.) ticks. The dogs were treated in the veterinary hospital and then the researchers went to their homes and the criteria to be included was the absence of fumigation for several months prior to the study in each house.

Blood samples were collected via jugular or cephalic venipuncture, and the samples were placed in tubes with and without EDTA (ethylenediaminetetraacetic acid). In the laboratory, the serum was separated by centrifugation and the whole blood and serum were stored at $-20^{\circ} \mathrm{C}$ until analysis.

At each home, ticks were collected directly from the dogs and from the environment (house walls and/or dogs houses). The collected ticks were sent to the Laboratory of Virology and Rickettsial Infections (LVR) of the Veterinary Hospital at the Federal University of Mato Grosso (HOVET-UFMT). The adult ticks were kept in absolute isopropyl alcohol until deoxyribonucleic acid (DNA) was extracted. The engorged nymphs collected from each animal or walls were preserved in a BOD (biochemical oxygen demand) incubator at a temperature of $27^{\circ} \mathrm{C}$ and $80 \%$ relative humidity in order to undergo ecdysis. All nymphs underwent ecdysis, were identified and stored in isopropyl alcohol until DNA extraction. The ticks were identified according to a specific taxonomic key for adults (Barros-Battesti et al., 2006). 


\section{Serological testing}

The serum samples were tested by indirect immunofluorescence assay (IFA) using DH82 cells infected with the isolated Cuiaba \#16 E. canis (Aguiar et al., 2013). Each slide contained nonreactive (negative control) and reactive (positive control; endpoint titer 1280) sera. The IFAT was performed according to Aguiar et al. (2007), and samples that reacted to the screening dilution (1:40) were then titrated using serial two-fold dilutions to determine the final titers.

\section{DNA extraction and PCR amplification}

Blood and ticks were subjected to DNA extraction using the guanidine thiocyanate-phenol protocol described by Sangioni et al. (2005). Extractions were performed individually per dog and tick. The extracted DNA was then identified and stored at $-20^{\circ} \mathrm{C}$ until completion of the polymerase chain reaction (PCR). The DNA of ticks was tested in pools of 3 adults according to the categories: engorged males, engorged females, post-ecdysis males and post-ecdysis females. In order to confirm the presence of genomic DNA in samples, the canine endogenous gene, glyceraldehyde-3-phosphate dehydrogenase (GAPDH) (Braga et al., 2016) and tick mitochondrial 16S rRNA gene were evaluated in a subset of randomized samples by PCR (Mangold et al., 1998).

The genomic DNA of blood samples and ticks was analyzed by real-time polymerase chain reaction (qPCR), aiming to amplify a fragment of 176-bp of the $d s b$ gene of Ehrlichia spp., using Dsb-330 sense (5'-GATGATGTCTGAAGATATGAAACAAAT-3') (Labruna et al., 2007) and Dsb-481 antisense primers (5'-TGCTTGTAATGTAGTGCTGCAT-3') (this paper), following the protocol involving 1.25 $\mathrm{U} \mathrm{GoTaq}^{\circledR} \mathrm{Hot}$ Start Polymerase (Promega ${ }^{\circledR}$ ), 5.0 $\mu$ L Flexi Buffer, $2.0 \mathrm{mM}$ $\mathrm{MgCl}_{2}$, dNTP mixture (0.2mM each), $0.5 \mu \mathrm{L}$ of each primer (10 pmol $/ \mu \mathrm{L}$ ), $0.2 \mu \mathrm{L} \mathrm{ROX}^{\mathrm{TM}}, 2.0 \mu \mathrm{L}$ SYBR Green, $0.5 \mu \mathrm{L}$ DNA and $10.05 \mu \mathrm{L}$ Nuclease Free Water (Promega ${ }^{\circledR}$ ), with a final volume of $25 \mu \mathrm{L}$, and performed in a StepOnePlus ${ }^{\mathrm{TM}}$ Real-Time PCR System. The amplification protocol consisted of an initial denaturation at $95^{\circ} \mathrm{C}$ for $15 \mathrm{sec}, 40$ cycles of denaturation $\left(95^{\circ} \mathrm{C}, 15 \mathrm{sec}\right)$, annealing $\left(60^{\circ} \mathrm{C} 15 \mathrm{sec}\right)$, immediately followed by a dissociation program consisting of $95^{\circ} \mathrm{C}$ for $15 \mathrm{sec}, 60^{\circ} \mathrm{C}$ for $1 \mathrm{~min}$ and $95^{\circ} \mathrm{C}$ for $15 \mathrm{sec}$. The dissociation curves with melting temperature (Tm) ranged from $76^{\circ} \mathrm{C}$ to $77^{\circ} \mathrm{C}$.

With the intention to determinate the sensibility of qPCR assay, DNA from the Cuiabá\# 1 strain of E. canis cultured in DH82 cells were submitted to a conventional
PCR using Dsb-330 and Dsb-481 primers. The amplicon was purified by the Illustra GFX PCR DNA and Gel Band Purification Kit (GE Healthcare ${ }^{\circledR}$ ) and then quantified in QubitR 2.0 Fluorometer (Life Invitrogen ${ }^{\circledR}$ ). The DNA sample was concentrated on $1 \mathrm{ng} / \mu \mathrm{L}$ followed by serial 10 -fold dilution and then submitted to the qPCR above described. The specificity of this new $d s b$ protocol for $E$. canis was determined by testing genomic DNA of E. chaffeensis and E. minasensis, which are the closest species related to $E$. canis. This species was obtained from cell culture of canine monocytes (DH82) in our laboratory.

The DNA of the tick pools that were positive for Ehrlichia spp. were then tested individually to determine the exact number of positive individuals. Subsequently, in order to obtain an amplicon of 409-bp of $d s b$ gene for sequencing analysis, positive samples were subjected to a PCR assay, according to the protocol described by Labruna et al. (2007), using DSB-330 sense and Dsb-728 antisense primers (5'-CTGCTCGTCTATTTTACTTCTTAAAGT-3'). The products of amplification were purified using Illustra GFX PCR DNA and Gel Band Purification Kit (GE Healthcare ${ }^{\circledR}$ ) commercial kits, according to the manufacturers' recommendations, and their sequences were determined on an automated DNA sequencer, Applied Biosystems 3500/3500xL Genetic Analyzer, following the manufacturer's instructions. The sequences thus obtained were compared by Blast (Basic Local Alignment Search Tool) Analysis with other Ehrlichia spp. sequences available in GenBank - NCBI (National Center for Biotechnology Information).

\section{Statistical analysis}

Confidence intervals (95\%) were calculated for prevalence rates in free-living ticks and ticks collected from dogs. The PCR results of each group were evaluated by the chi-square test. Values were considered significant at $P<0.05$.

\section{Results}

To ensure DNA extraction from dogs and ticks samples, PCR targeting GAPDH and tick mitochondrial genes respectively were applied. All tested samples resulted positive.

Sensibility and specificity. The sensibility of qPCR assay using the primer Dsb-481 of Ehrlichia. The positivity was observed until the $10^{\text {th }}$ dilution ( $1 / 2$ copy of DNA) which means 2 copies of $E$. canis $d s b$ gene in $4 \mu \mathrm{L}$ of DNA template. PCR product was not amplified from $E$. chaffeensis but was positive for E. minasensis DNA extracted from cell culture.

Dogs. Nine (45\%) of the 20 dogs were seropositive for E. canis. Antibody titers ranged from 80 to 10240 (Table 1). Six dogs (30\%) were positive for Ehrlichia spp. by PCR and 
Table 1 - Number of homes, dogs and collected ticks from 17 neighborhoods of Cuiabá evaluated for the presence of Ehrlichia canis

\begin{tabular}{|c|c|c|c|c|c|c|}
\hline \multirow{2}{*}{ Home } & \multicolumn{4}{|c|}{ Dogs } & \multicolumn{2}{|r|}{ Ticks } \\
\hline & Number & Evaluated & PCR & IFA Titer & Collected & Positive \\
\hline 1 & 2 & 1 & Neg & NR & 19 & 0 \\
\hline 2 & 1 & 1 & Neg & NR & 16 & 1 post-ecdysis female from wall \\
\hline 3 & 1 & 1 & Neg & NR & 15 & 0 \\
\hline 4 & 1 & 1 & Neg & NR & 8 & 0 \\
\hline 5 & 2 & 1 & Pos & 2560 & 15 & 1 female collected from wall \\
\hline 6 & 1 & 1 & Neg & NR & 21 & 0 \\
\hline 7 & 1 & 1 & Pos & 5120 & 24 & 0 \\
\hline 8 & 1 & 1 & Neg & NR & 12 & 0 \\
\hline 9 & 1 & 1 & Neg & 640 & 21 & 0 \\
\hline 10 & 1 & 1 & Neg & NR & 12 & 1 female collected from a dog \\
\hline 11 & 2 & 1 & Neg & 2560 & 8 & 1 female collected from a dog \\
\hline 12 & 1 & 1 & Neg & 80 & 18 & 1 female collected from a dog \\
\hline 13 & 1 & 1 & Pos & NR & 15 & 0 \\
\hline 14 & 3 & 1 & Neg & 1280 & 10 & 1 male collected from a dog \\
\hline 15 & 1 & 1 & Pos & 10240 & 15 & 0 \\
\hline 16 & 1 & 1 & Pos & 10240 & 14 & 2 males collected from a dog \\
\hline 17 & 1 & 1 & Neg & NR & 16 & 1 male and 2 females from wall \\
\hline 18 & 1 & 1 & Pos & NR & 12 & 0 \\
\hline 19 & 1 & 1 & Neg & NR & 16 & 0 \\
\hline 20 & 1 & 1 & Neg & 160 & 12 & 0 \\
\hline
\end{tabular}

$\mathrm{NR}=$ Not reactive.

their average titer $(n=6$, average titer $=4693.3)$ was higher than that of the PCR negative dogs $(n=5$, average titer=944). Only two dogs testing positive by PCR had no antibodies. There was no association between PCR positive dogs and seroreactivity by IFAT.

Ticks. At the homes, 127 engorged nymphs (95 from walls and 32 from dogs), 78 adult males ( 33 from walls and 45 from dogs), 94 adult females ( 47 from walls and 47 from dogs) were collected. A total of 299 ticks (175 from walls and 124 attached to dogs) were identified as belonging to the $R$. sanguineus complex. The DNA of pools that were PCR positive was tested individually, resulting in 5 (2.89\%; 95\% confidence interval: $0.94 \%-6.62 \%)$ positive free-living ticks: 1 male and 4 females ( 1 non-engorged post-ecdysis and 3 non-engorged). Six positive ticks were attached to dogs (4.76\%; 95\% CI: $1.77-10.0 \%)$, three males and three females. The two groups showed a similar infection rate $(\mathrm{P}=0.395)$. Partial $d s b$ DNA sequences from 2 samples from ticks were identical to each other and 100\% (350/350 nucleotides) identical to E. canis (GenBank CP000107).

\section{Discussion}

The present study evaluated the E. canis infection rates in a population of $R$. sanguineus s.l. ticks in the central region of Brazil. The city of Cuiabá is located in the exact center of South America, and its warm tropical and sub-humid climate is favorable for the maintenance of $R$. sanguineus s.l. tick populations (Jacobs et al., 2001; Louly et al., 2007).
Hence, the occurrence of dogs from this city parasitized by ticks is usually high throughout the year (personal information). In this way to avoid analyzing places under effect of treatment, the criterion of inclusion of the tick population was based on the history of parasitism by $R$. sanguineus in dogs living in environments that had not been fumigated for several recent months prior to this study.

For this study, a new protocol to detect DNA from E. canis was developed based on a qPCR assay targeting fragment of the $d s b$ gene. The sensibility observed for E. canis (2 copies) supported its application for diagnostic procedures or epidemiological inquiries in our region, which is considered endemic for canine ehrlichiosis. In the other side, the primers were not specific for $E$. canis since they amplified $d s b$ fragments of E. minasensis. Ehrlichia canis and E. minasensis are two related species from the Ehrlichia genus. These two species have been evolved from a variable clade within the genus, and this proximity could difficult a better PCR specificity (Cabezas-Cruz et al., 2014).

According to the PCR and IFA analyses, 30\% $(\mathrm{n}=6)$ and $45 \%(n=9)$ of the dogs were positive, respectively. These data corroborate previous results reported for the region (Silva et al., 2010; Witter et al., 2013), which described Cuiabá as an endemic area for ehrlichiosis in Brazil. Two of the dogs in this study were seronegative, but Ehrlichia spp. DNA was identified in their blood. Most dogs become seropositive after 28 days of infection (Harrus et al., 1997), although 
DNA can be identified 14 days after infection, characterizing the acute phase of ehrlichiosis (Aguiar et al., 2007).

Despite their different origins, the PCR results showed no difference between free-living ticks collected directly from house walls, and ticks attached to dogs. Ticks collected from dogs that tested positive can be associated with rickettsemia (e.g., the blood sample of a dog from house \#16 was positive and the ticks attached to it were also positive). On the other hand, although ticks in the parasitic phase were positive, the dogs to which they were attached were PCR negative (house \# 10,11, 12 and 14). Three of these dogs were seropositive, suggesting the chronic phase, when some cycles of bacteremia can occur, at which time ticks are susceptible to infection. The seronegative dogs and the PCR negative dog (house \#10) were parasitized by positive $R$. sanguineus ticks, exemplifying the period when natural transmission of $E$. canis by the tick may occur.

In this regard, positive ticks were collected from the walls of homes \#2 and \#17 where seronegative and PCR negative dogs lived. According to Aguiar et al. (2007), the maintenance of $E$. canis in the environment or in $R$. sanguineus populations requires dogs suffering from rickettsemia, since transplacental transmission does not occur in ticks. Hence, ticks cannot maintain E. canis infections for more than one generation. On the other hand, adults of $R$. sanguineus ticks are able to keep E. canis viable for up to 155 days after molt (Lewis et al., 1977). Therefore, even without the presence of an infected dog living at a site, in some circumstances, unfed adult $R$. sanguineus ticks can survive for long periods and may be able to infect susceptible dogs.

\section{References}

Aguiar DM, Cavalcante GT, Pinter A, Gennari SM, Camargo LMA, Labruna MB. Prevalence of Ehrlichia canis (Rickettsiales: Anaplasmataceae) in dogs and Rhipicephalus sanguineus (Acari: Ixodidae) ticks from Brazil. J Med Entomol. 2007;44(1):126-32. http://dx.doi.org/10.1603/00222585(2007)44[126:POECRA]2.0.CO;2. PMid:17294930.

Aguiar DM, Zhang X, Melo ALT, Pacheco TA, Meneses AM, Zanutto MS, Horta MC, Santarém VA, Camargo LM, McBride JW, Labruna MB. Genetic diversity of Ehrlichia canis in Brazil. Vet Microbiol. 2013;164(3-4):315-21. http:// dx.doi.org/10.1016/j.vetmic.2013.02.015. PMid:23490559.

Barros-Battesti DM, Arzua M, Bechara GH. Carrapatos de importância medico-veterinária da região neotropical. São Paulo: Vox/ICTTD-3/Butantã; 2006.

\section{Conclusion}

The development of a new and sensitive diagnostic tool for detection of Ehrlichia spp. was reported. Despite the high serological and molecular rates of canine ehrlichiosis in Cuiabá, the prevalence rate of infected ticks was much lower than that of dogs. However, adult ticks may remain infective much longer to ensure their infestation and infection of susceptible dogs.

\section{Conflict of Interest}

The authors state they have no conflicts of interest to declare.

\section{Ethics Statement}

This study was evaluated by the Animal Research Ethics Committee of the Federal University of Mato Grosso and was approved under Protocol no. 23108.051170/10-0.

\section{Acknowledgements}

We thank to Prestaserv for help in finding some homes infested by ticks, and Foundation for Research Support for the state of Mato Grosso (FAPEMAT) (263287/2010) and National Council for Scientific and Technological Development (CNPq) (472206/2011-7) for their financial support. We also thank to Coordination of Improvement of Higher Education Personnel (CAPES), Ministry of Education of Brazil (MEC) and CNPq for the scholarships of J.S. Costa, A.L.T. Melo, R. Witter, T.A. Pacheco, C.S. Chitarra, I.T.S. Carvalho, and for Scientific Productivity Grant to V. Dutra, L. Nakazato, R.C. Pacheco, and D.M. Aguiar.

Braga ÍA, Ramos DGS, Marcili A, Melo ALT, Taques IIGG, Amude AM, Chitarra CS, Nakazato L, Dutra V, Pacheco RC, Aguiar DM. Molecular detection of tick-borne protozoan parasites in a population of domestic cats in midwestern Brazil. Ticks Tick Borne Dis. 2016;7(5):1004-9. http:// dx.doi.org/10.1016/j.ttbdis.2016.05.007. PMid:27260253.

Bremer WG, Schaefer JJ, Wagner ER, Ewing SA, Rikihisa Y, Needham GR, Jittapalapong S, Moore DL, Stich RW. Transstadial and intrastadial experimental transmission of Ehrlichia canis by male Rhipicephalus sanguineus. Vet Parasitol. 2005;131(1-2):95-105. http://dx.doi.org/10.1016/j. vetpar.2005.04.030. PMid:15941624.

Cabezas-Cruz A, Valdés JJ, De la Fuente J. The glycoprotein TRP36 of Ehrlichia sp. UFMG-EV and related cattle pathogen 
Ehrlichia sp. UFMT-BV evolved from a highly variable clade of $E$. canis under adaptive diversifying selection. Parasit Vectors. 2014;7(1):584. http://dx.doi.org/10.1186/ s13071-014-0584-5. PMid:25499826.

Cabezas-Cruz A, Zweygarth E, Vancová M, Broniszewska M, Grubhoffer L, Passos LM, Ribeiro MF, Alberdi P, De la Fuente J. Ehrlichia minasensis sp. nov., a new species within the genus Ehrlichia isolated from the tick Rhipicephalus microplus. Int J Syst Evol Microbiol. 2016;66(3):1426-30. http://dx.doi.org/10.1099/ijsem.0.000895. PMid:26763978.

Dantas-Torres F. Biology and ecology of the brown dog tick, Rhipicephalus sanguineus. Parasit Vectors. 2010;3(1):26. http://dx.doi.org/10.1186/1756-3305-3-26. PMid:20377860.

Dumler JS, Barbet AF, Bekker CPJ, Dasch GA, Palmer GH, Ray SC, Rikihisa Y, Rurangirwa FR. Reorganization of genera in the families Rickettsiaceae and Anaplasmataceae in the order Rickettsiales: unification of some species of Ehrlichia with Anaplasma, Cowdria with Ehrlichia and Ehrlichia with Neorickettsia, descriptions of six new species combinations and designation of Ehrlichia equi and 'HE agent' as subjective synonyms of Ehrlichia phagocytophila. Int J Syst Evol Microbiol. 2001;51(6):2145-65. http://dx.doi. org/10.1099/00207713-51-6-2145. PMid:11760958.

Harrus S, Kass PH, Klement E, Waner T. Canine monocytic ehrlichiosis: a retrospective study of 100 cases, and an epidemiological investigation of prognostic indicators for the disease. Vet Rec. 1997;141(14):360-3. http://dx.doi. org/10.1136/vr.141.14.360. PMid:9351183.

IBGE: Instituto Brasileiro de Geografia e Estatística [Internet]. Rio de Janeiro: IBGE; 2018 [cited 2019 Jan 17]. Available from: https://cidades.ibge.gov.br/brasil/mt/cuiaba/panorama

Jacobs PA, Fourie LJ, Kok DJ, Horak IG. Diversity, seasonality and sites of attachment of adult ixodid ticks on dogs in the central region of the Free State Province, South Africa. Onderstepoort J Vet Res. 2001;68(4):281-90. PMid:12026063.

Labruna MB, Mcbride JW, Camargo LMA, Aguiar DM, Yabsley MJ, Davidson WR, Stromdahl EY, Williamson PC, Stich RW, Long SW, Camargo EP, Walker DH. A preliminary investigation of Ehrlichia species in ticks, humans, dogs, and capybaras from Brazil. Vet Parasitol. 2007;143(2):189-95. http://dx.doi.org/10.1016/j.vetpar.2006.08.005. PMid:16962245.

Lewis GE Jr, Ristic M, Smith RD, Lincoln T, Stephenson $\mathrm{EH}$. The brown dog tick Rhipicephalus sanguineus and the dog as experimental hosts of Ehrlichia canis. Am J Vet Res. 1977;38(12):1953-5. PMid:596693.
Louly CCB, Fonseca IN, Oliveira VF, Linhares GFC, Menezes LB, Borges LMF. Seasonal dynamics of Rhipicephalus sanguineus (Acari: Ixodidae) in dogs from a police unit in Goiânia, Goiás, Brazil. Cienc Rural. 2007;37(2):464-9. http://dx.doi.org/10.1590/S0103-84782007000200026.

Makino H, Sousa VRF, Fujimori M, Rodrigues JY, Dias AFLR, Dutra V, Nakazato L, Almeida ABPF. Ehrlichia canis detection in dogs from Várzea Grande: a comparative analysis of blood and bone marrow samples. Cienc Rural. 2015;46(2):310-4 http://dx.doi.org/10.1590/0103-8478cr20150090.

Mangold AJ, Bargues MD, Mas-Coma S. Mitochondrial 16S rDNA sequences and phylogenetic relationships of species of Rhipicephaus and other tick genera among Metastriata (Acari: ixodidae). Parasitol Res. 1998;84(6):478-84. http:// dx.doi.org/10.1007/s004360050433. PMid:9660138.

Moraes-Filho J, Marcili A, Nieri-Bastos FA, Richtzenhain LJ, Labruna MB. Genetic analysis of ticks belonging to the Rhipicephalus sanguineus group in Latin America. Acta Trop. 2011;117(1):51-5. http://dx.doi.org/10.1016/j. actatropica.2010.09.006. PMid:20858451.

Pegram RG, Clifford CM, Walker JB, Keirans JE. Clarification of the Rhipicephalus sanguineus group (Acari, Ixodoidae, Ixodidae) I. R. sulcatus Neumann, 1908 and $R$. turanicus Pomerantsev, 1936. Syst Parasitol. 1987;10(1):3-26. http:// dx.doi.org/10.1007/BF00009099.

Sangioni LA, Horta MC, Vianna MCB, Gennari SM, Soares RM, Galvão MA, Schumaker TT, Ferreira F, Vidotto O, Labruna MB. Rickettsial infection in animals and Brazilian spotted fever endemicity. Emerg Infect Dis. 2005;11(2):265-70. http://dx.doi.org/10.3201/eid1102.040656. PMid:15752445.

Silva JN, Almeida ABPF, Boa Sorte EC, Freitas AG, Santos LGF, Aguiar DM, Sousa VRF. Seroprevalence anti-Ehrlichia canis antibodies in dogs of Cuiabá, Mato Grosso. Rev Bras Parasitol Vet. 2010;19(2):108-11. http://dx.doi.org/10.1590/ S1984-29612010000200008. PMid:20624348.

Vieira RFC, Biondo AW, Guimarães AMS, Santos AP, Santos RP, Dutra LH, Diniz PPVP, Morais HA, Messick JB, Labruna MB, Vidotto O. Ehrlichiosis in Brazil. Rev Bras Parasitol Vet. 2011;20(1):1-12. http://dx.doi.org/10.1590/ S1984-29612011000100002. PMid:21439224.

Walker JB, Keirans JE, Horak IG. The genus rhipicephalus (Acari, Ixodidae): a guide to the brown ticks of the world. Trop Anim Health Prod. 2000;32(6):417-8. http://dx.doi. org/10.1023/A:1005237804239. 
Witter R, Vecchi SN, Pacheco TA, Melo ALT, Borsa A, Sinkoc AL, Mendonça AJ, Aguiar DM. Prevalence of canine monocitic ehrlichiosis and canine thrombocytic anaplasmosis in dogs suspected of hemoparasitosis in Cuiabá, Mato Grosso. Semina: Ciênc Agrár. 2013;34(6):3811-22. http://dx.doi.org/10.5433/16790359.2013v34n6Supl2p3811.

Financial Support: Foundation for Research Support for the state of Mato Grosso (FAPEMAT) (263287/2010) and National Council for Scientific and Technological Development (CNPq) (472206/2011-7).
Authors Contributions: Jackeliny dos Santos Costa participated in the execution and confection of the manuscript. Andréia Lima Tomé Melo participated in the planning and execution of the manuscript. Rute Witter participated in the execution of the manuscript. Thábata dos Anjos Pacheco participated in the execution of the manuscript. Cristiane Silva Chitarra participated in the execution of the manuscript. Izabelle Thayná Soares Carvalho participated in the execution of the manuscript. Luciano Nakazato participated in the execution of the manuscript. Valéria Dutra participated in the execution of the manuscript. Daniel Moura de Aguiar participated in the planning and confection of the manuscript. 